\title{
Induction of heat shock response in Vibrio cholerae
}

\author{
JeevanJyot and Amit Ghosh
}

Author for correspondence: Amit Ghosh. Tel: +91 172 690751. Fax: +91 172690585.

Institute of Microbial Technology, Sector 39 A, Chandigarh - 160014 , India

\begin{abstract}
General properties of the heat shock response in Vibrio cholerae were examined. Enhanced or de novo synthesis of 24 proteins was observed upon heat shock from $30^{\circ} \mathrm{C}$ to $42{ }^{\circ} \mathrm{C}$ in cells labelled with [ [35]methionine. A similar response could also be induced by a rise in temperature from $30^{\circ} \mathrm{C}$ to $37^{\circ} \mathrm{C}$. Of these heat shock proteins, two were determined to be homologues of GroEL and DnaK, based upon their immunological cross-reactivity with antibodies raised against the Escherichia coli proteins. Three proteins, of molecular sizes 38,44 and $48 \mathrm{kDa}$, which were undetectable in the $30^{\circ} \mathrm{C}$ grown culture, appeared de novo after the heat shock. As in other prokaryotic systems thermal induction of many of the proteins was transient, but both DnaK and GroEL remained induced for at least $28 \mathrm{~min}$ after heat shock. DNA hybridization studies revealed that genes analogous not only to dnaK and groEL but also to dnaJ of $E$. colf exist in $V$. cholerae. Heat shock induced thermotolerance in $V$. cholerae but made the cells more sensitive to UV radiation. Unlike in $E$. coll, however, heat shock had no effect on the progeny virus yield in $\mathbf{V}$. cholerae.
\end{abstract}

Keywords: heat shock, Vibrio cholerae, DnaK, GroEL

\section{INTRODUCTION}

Exposure of cells and organisms to an abrupt increase in temperature triggers the induction of a phenomenon known as the heat shock response. This response, which appears to be universally present from microbes to mammals (Yura et al., 1993), is characterized by the enhanced synthesis of a set of proteins, called the heat shock proteins (Hsps). Various forms of stressful stimuli, besides heat shock, can lead to the increased synthesis of Hsps and it is generally believed that these proteins protect cells from stress (Watson, 1990). Under non-stress conditions many of the Hsps play fundamental roles in normal cellular physiology (Yura et al., 1993).

Stress proteins are synthesized when an invading pathogen finds itself in a hostile milieu inside the host. In a number of pathogens, many of these Hsps evoke a strong immune response in their hosts (Watson, 1990). The disease cholera in humans is caused by ingestion of the Gram-negative bacterium Vibrio cholerae, which is widely distributed in nature in a 'quiescent' form associated with diverse forms of surface marine life (Epstein et al., 1993). As it enters the human body it immediately encounters a variety of stressful stimuli such as elevated temperature, extremes of $\mathrm{pH}$, and different available nutrients, which it has to combat successfully before it can reach the intestinal epithelium and proliferate there. How $V$. cholerae responds to these challenges is not known, as very little work has been done on the heat shock response in this organism. Until very recently a study by Parsot \& Mekalanos (1990) showing the presence of the heat shock gene $b t p G$ and the role it plays in modulating the expression of ToxR, the transcriptional activator of the virulence factors in $V$. cholerae, was the only paper on the subject. It was in this context that we examined the heat shock response in $V$. cholerae. However, after this paper was submitted, another paper (Sahu et al., 1994) on the heat shock response and Hsp antigens of $V$. cholerae, which overlaps considerably with our work, appeared in the literature. Further, in another very interesting study, use of the inducible $b t p G$ promoter to express the B subunit of $V$. cholerae toxin for the construction of a live attenuated cholera vaccine has also recently been reported (Taylor et al., 1994).

\section{METHODS}

Bacteria, phage, plasmids and media. The bacterial strains, phage and plasmids used in this study are listed in Table 1. Growth in LB, bacterial storage conditions and phage techniques have been as described (Siddiqui \& Ghosh, 1983; Mitra et al., 1986; Basu et al., 1993). Composition of the synthetic medium MM9, and the procedure for adapting $V$. cholerae to grow on this medium, have also been described (Chakravarti \& Ghosh, 1987). 
Table 1. Bacterial strains, phage and plasmids

\begin{tabular}{|c|c|c|}
\hline $\begin{array}{l}\text { Bacterium, phage or } \\
\text { plasmid }\end{array}$ & Relevant genotype or phenotype & Source \\
\hline \multicolumn{3}{|l|}{ Bacteria } \\
\hline E. coli $\mathrm{B}$ & Wild-type & Laboratory stock \\
\hline$V$. cholerae MAK757 & El Tor prototroph & Laboratory stock \\
\hline \multicolumn{3}{|l|}{ Phage } \\
\hline$\phi 72$ & Lysogenic vibriophage & $\begin{array}{l}\text { Dr S. N. Mitra, } \\
\text { IICB, Calcutta }\end{array}$ \\
\hline \multicolumn{3}{|l|}{ Plasmids } \\
\hline $\mathrm{pBR}-\mathrm{dnaK} \mathrm{K}^{+}$ & $\begin{array}{l}\text { As pBR322 with a } 5.3 \mathrm{~kb} \text { HindIII } \\
\text { fragment with } d n a K \text { and part of } d n a J\end{array}$ & Dr Kit Tilly \\
\hline pLS1 & $\begin{array}{l}\text { As pBR322 with an } 8 \mathrm{~kb} E c o R I \\
\text { fragment with both groE genes }\end{array}$ & Dr Kit Tilly \\
\hline pXM86 & $\begin{array}{l}\text { As pJK10 with a } 0.9 \mathrm{~kb} \text { HindIII } \\
\text { fragment of dnaJ }\end{array}$ & Dr Kit Tilly \\
\hline pGB2-grp $E^{+}$ & $\begin{array}{l}\text { As pGB2 with a } 1.6 \mathrm{~kb} \text { EcoRI-HincII } \\
\text { fragment of } g r p E^{+}\end{array}$ & Dr Kit Tilly \\
\hline
\end{tabular}

High-temperature survival profile. $V$. cholerae MAK757 was grown at $30^{\circ} \mathrm{C}$ to mid-exponential phase $\left(2-3 \times 10^{8}\right.$ cells $\left.\mathrm{ml}^{-1}\right)$; cells were then heat-shocked at $42^{\circ} \mathrm{C}, 45^{\circ} \mathrm{C}$ and $50^{\circ} \mathrm{C}$ by transferring aliquots to a set of flasks maintained at the desired temperatures in a water bath. The temperature equilibrium was reached within $1 \mathrm{~min}$ of transfer. Survival of cells was determined by withdrawing aliquots at various times and plating. Cell survival just before the heat shock was assigned the $100 \%$ value.

Thermotolerance. An exponential-phase culture of $V$. cholerae grown as above was subjected to a thermal stress of $50^{\circ} \mathrm{C}$, either directly or after a heat shock treatment at $42{ }^{\circ} \mathrm{C}$ for $20 \mathrm{~min}$. Aliquots were withdrawn at specified intervals to determine viable cell counts.

UV irradiation. Three sets of cultures were exposed to UV radiation. The control consisted of cells grown at $30^{\circ} \mathrm{C}$ as described. The second and third sets consisted of cells heatshocked to $42^{\circ} \mathrm{C}$ for 30 and $60 \mathrm{~min}$ prior to UV exposure. Cells were diluted in MM9 buffer to $1 \times 10^{6}$ cells $\mathrm{ml}^{-1}$ and UVirradiated as described previously (Basu \& Ghosh, 1987). Incident UV dose was determined by chemical actinometry (Hatchard \& Parker, 1956).

Reproducibility of survival experiments. Each of the above three experiments were performed at least three times and for each time point duplicate samples were withdrawn. Data analysis was performed using Sigma Plot.

One-step growth experiment. One-step growth experiments (Ellis \& Delbruck, 1939) were performed to determine the burst size of cholera phage $\phi 72$ in $V$. cholerae MAK757 under different growth conditions. In the control set, mid-exponential-phase cells of MAK 757 were infected with $\phi 72$ at a multiplicity of infection 0.1 and kept at $30^{\circ} \mathrm{C}$ for $5 \mathrm{~min}$, after which platings for unadsorbed phage count and the 0 min plaque count were done (after appropriate dilutions). The phage infection cycle was allowed to proceed at $30^{\circ} \mathrm{C}$. Phage platings were done every $10 \mathrm{~min}$ until $70 \mathrm{~min}$. In another set, the cells were infected with phage at $30^{\circ} \mathrm{C}$ for $8 \mathrm{~min}$ and then heat-shocked to $42^{\circ} \mathrm{C}$. The third set involved a heat shock to $42^{\circ} \mathrm{C}$ for $8 \mathrm{~min}$ before infecting the cells with phage. In both cases the rest of the infection cycle was allowed to proceed at $42^{\circ} \mathrm{C}$. The burst size for each set was calculated and compared.

Protein labelling. $V$. cholerae cultures were grown overnight in MM9 medium without Casamino acids but supplemented with an amino acid mixture according to Maloy (1990). Subculturing to obtain exponential-phase cells was done in the same medium with the methionine concentration reduced 10-fold. Labelling was initiated at different times after the temperature shift-up by adding $1 \mathrm{ml}$ cells to prewarmed vials containing $15 \mu \mathrm{Ci}$ $\left[{ }^{35}\right.$ S $]$ methionine (sp. act. $300 \mu \mathrm{Ci} \mathrm{mmol}{ }^{-1} 11 \cdot 1 \mathrm{MBq} \mathrm{mmol}^{-1}$; Bhabha Atomic Research Centre, Bombay). Labelling was terminated at the end of the stipulated time by chilling the samples to $0{ }^{\circ} \mathrm{C}$ and pelleting the cells in an Eppendorf microfuge for $1 \mathrm{~min}$. Incorporation of radioactivity into nascent proteins was determined by TCA precipitation as described previously (Ghosh et al., 1978).

Protein gels. Aliquots $(1 \mathrm{ml})$ of cells either unlabelled or labelled with $\left[{ }^{35} \mathrm{~S}\right]$ methionine (as described above) were withdrawn at various times after the heat shock treatment, chilled to $0{ }^{\circ} \mathrm{C}$ and then pelleted by centrifugation. The cell pellet was lysed in $40 \mu \mathrm{l}$ sample buffer. Sample buffer contained, per $100 \mathrm{ml}: 10 \mathrm{ml}$ TBS buffer $(0.41 \mathrm{M}$ Tris, $0.40 \mathrm{M}$ boric acid, $1 \%$, $\mathrm{w} / \mathrm{v}$, SDS, pH 8.64), $5 \mathrm{~g}$ sucrose, $185 \mathrm{mg}$ EDTA, $5 \mathrm{ml} \mathrm{2-}$ mercaptoethanol, $1.9 \mathrm{~g}$ SDS (Dascher et al., 1990) and $5 \mathrm{ml}$ glycerol. The total protein content of samples was assayed according to Bradford (1976). The samples were then analysed on a vertical SDS-polyacrylamide gel with a $4 \%(\mathrm{w} / \mathrm{v})$ stacking and an $8 \%, 10 \%$ or $12.5 \%(\mathrm{w} / \mathrm{v})$ resolving gel (Laemmli, 1970). Gels were fixed and then either stained with Coomassie brilliant blue or autoradiographed after fluorography with DMSO/PPO (Sambrook et al., 1989). Densitometric scans of the autoradiographs were performed with a laser densitometer (LKB Bromma 2202). Molecular mass determinations of the protein bands with respect to the standard markers were determined using the program SEQAIDrr.

Western blotting. Protein samples electrophoresed on an $8 \%$ SDS-polyacrylamide gel were transblotted onto a $0.45 \mu \mathrm{m}$ nitrocellulose membrane filter (Advanced Microdevices) using a Bio-Rad electroblotter. Primary antibodies, anti-DnaK and anti-GroEL, that had been raised in rabbits (obtained from $\mathrm{Dr}$ 
Roger McMacken, Johns Hopkins University, and Dr Kathee Martincic, University of Pittsburgh, through the courtesy of Dr D. K. Chattoraj, NIH, USA), were used at 1:5000 and 1:3000 dilutions respectively. Secondary antibodies were anti-rabbit goat antibodies linked to alkaline phosphatase. Western blotting was done as described previously (Bhasin \& Ghosh, 1995; Vaughan et al., 1991).

Southern hybridizations. Genomic DNA of $V$. cholerae MAK757 was prepared (Mekalanos, 1983) and digested with various restriction enzymes according to the manufacturer's instructions. The DNA fragments were resolved on a $0.7 \%$ agarose gel. The gel was processed as described in the Hybond Instruction Manual (Amersham), with a few modifications. The depurination was done for $30 \mathrm{~min}$, denaturation and neutralization were for $1 \mathrm{~h}$ each and blotting was done using $10 \times$ SSC. The nylon membrane was dried and baked for $2 \mathrm{~h}$ at $80^{\circ} \mathrm{C}$. The hybridization was carried out at $58^{\circ} \mathrm{C}$. The probes, $5.3 \mathrm{~kb}$ HindIII fragment of pBR-dnaK ${ }^{+}$(Bardwell \& Craig, 1984) for $d n a K, 0.9 \mathrm{~kb}$ HindIII fragment of pXM86 (Bardwell et al., 1986) for dnaJ, $1.6 \mathrm{~kb}$ EcoRI-HincII fragment of pGB2grp $E^{+}$(Churchward et al., 1984) for grpE, and $8 \mathrm{~kb}$ EcoRI fragment of pLS1 (Chandrasekhar et al., 1986) for both groEL and groES, were labelled with ${ }^{32} \mathrm{P}$ by nick-translation (Rigby $e t$ al., 1977). Washings were done at room temperature for $10 \mathrm{~min}$, and the blots exposed for autoradiography at $-70^{\circ} \mathrm{C}$.

Reproducibility. All the protein labelling, blotting and hybridization experiments were repeated at least three times. Results of typical experiments are presented.

\section{RESULTS}

\section{Effect of heat shock on the growth of $V$. cholerae MAK757}

Viability of $V$. cholerae MAK 757 grown at $30^{\circ} \mathrm{C}$ after temperature shifts to $42{ }^{\circ} \mathrm{C}, 45^{\circ} \mathrm{C}$ or $50^{\circ} \mathrm{C}$ was determined (Fig. 1). A drastic reduction in viability resulted when cells were heat-shocked to $50^{\circ} \mathrm{C}$ : more than $99 \%$ of

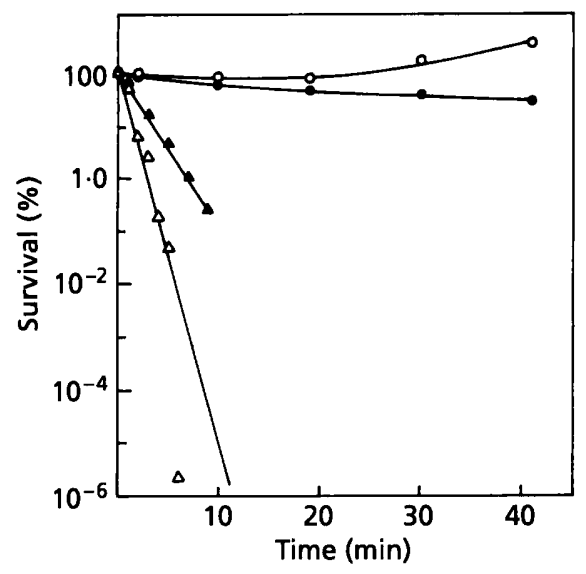

Fig. 1. Survival profiles and induced thermotolerance in $V$. cholerae MAK757. Cells grown at $30^{\circ} \mathrm{C}$ to mid-exponential phase $\left(1.7-1.9 \times 10^{8}\right.$ cells $\left.\mathrm{ml}^{-1}\right)$ were heat-shocked at $0 \mathrm{~min}$ to $42^{\circ} \mathrm{C}(O), 45^{\circ} \mathrm{C}(O)$ and $50^{\circ} \mathrm{C}(\triangle)$, and survival was determined after incubation at these temperatures for various times. A temperature upshift to $42^{\circ} \mathrm{C}$ for $20 \mathrm{~min}$ prior to cell transfer to $50^{\circ} \mathrm{C}(\boldsymbol{\Delta})$ enabled the cells to acquire thermotolerance. the cells were killed within 5 min of shift-up. In contrast, only a marginal loss of viability was observed at $42^{\circ} \mathrm{C}$ even after $20 \mathrm{~min}$; moreover, cells were able to recover quickly and the cell doubling time decreased from $40 \mathrm{~min}$ at $30^{\circ} \mathrm{C}$ to $15 \mathrm{~min}$ at $42{ }^{\circ} \mathrm{C}$. A temperature shift-up to $45^{\circ} \mathrm{C}$ resulted in nearly $50 \%$ killing within 20 min with no subsequent recovery. Based on the above results and in order to have an appreciable temperature differential, $42{ }^{\circ} \mathrm{C}$ was used as the heat shock temperature for the studies reported in this paper.

\section{Influence of heat shock on the effect of subsequent exposure of $V$. cholerae to heat and UV radiation}

Some organisms, like yeast (McAlister \& Finkelstein, 1980), Neurospora crassa (Plesofsky-Vig \& Brambl, 1985), and some strains of E. coli (e.g. E. coli B: Pardasani \& Fitt, 1989), develop transient resistance against the killing effects of temperatures normally lethal to them, if they are previously subjected to a non-lethal heat shock. The K12 derivatives of E. coli, however, do not acquire thermotolerance (Pardasani \& Fitt, 1989). To examine the situation in $V$. cholerae, a culture growing exponentially at $30^{\circ} \mathrm{C}$ was heat-shocked to $42{ }^{\circ} \mathrm{C}$ for 20 min prior to its exposure to $50^{\circ} \mathrm{C}$. The heat-shocked cells became much more resistant to the killing effects of thermal stress, compared to the control (Fig. 1).

Heat shock can also confer resistance to UV in yeast and in some strains of E. coli, namely the $\mathrm{K} 12$ derivatives. However, it made $E$. coli $B$ more sensitive to UV (Pardasani \& Fitt, 1989). Heat shock thus produces opposite effects in $\mathrm{K} 12$ and B strains of E. coli in respect of their response to UV and thermal stress. When the response of $V$. cholerae to UV after heat shock was examined, it was found that heat shock made the cells more sensitive to UV (data not shown). The response of heat-shocked $V$. cholerae towards both UV and thermal stress was thus similar to that of E. coli B.

\section{Heat shock and cholera phage growth}

An aspect of the heat shock response in E. coli is that if cells are adapted to grow at a high but non-lethal temperature before being infected with a phage, then the progeny virus yield at that temperature greatly increases (Wiberg et al., 1988). We used the temperate cholera phage $\phi 72$, with a double-stranded DNA genome of $38 \mathrm{~kb}$ (our unpublished observation) to examine this aspect of the heat shock response in $V$. cholerae. Adaptation of $V$. cholerae to $42{ }^{\circ} \mathrm{C}$ for $8 \mathrm{~min}$ prior to infection with $\phi 72 \mathrm{led}$ to only a marginal increase $(1.5-1.6$ fold $)$ in progeny virus yield, compared to the control where cells grown at $30^{\circ} \mathrm{C}$ for several generations were infected for $8 \mathrm{~min}$ before being shifted to $42{ }^{\circ} \mathrm{C}$ (data not shown).

\section{Effect of heat shock on protein synthesis}

When an exponential-phase culture of $V$. cholerae MAK757 growing at $30^{\circ} \mathrm{C}$ was shifted to $42{ }^{\circ} \mathrm{C}$, no reduction in the overall rate of protein synthesis was 


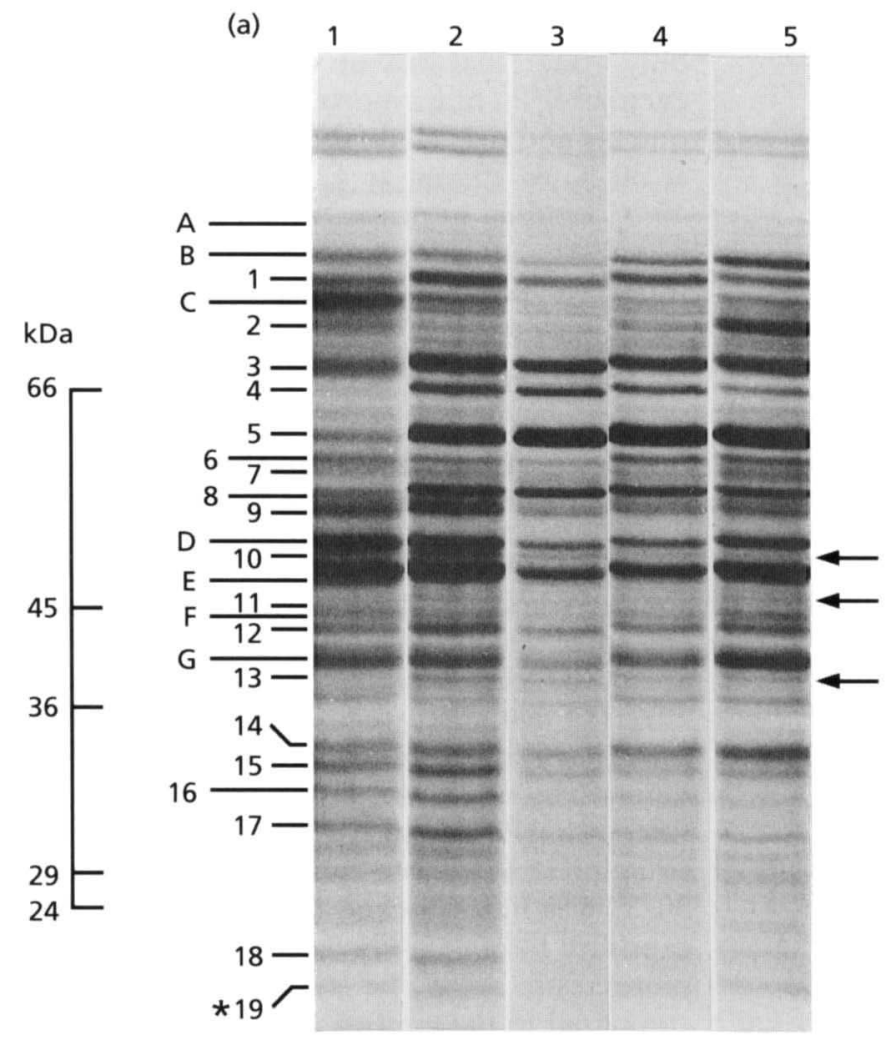

(b)

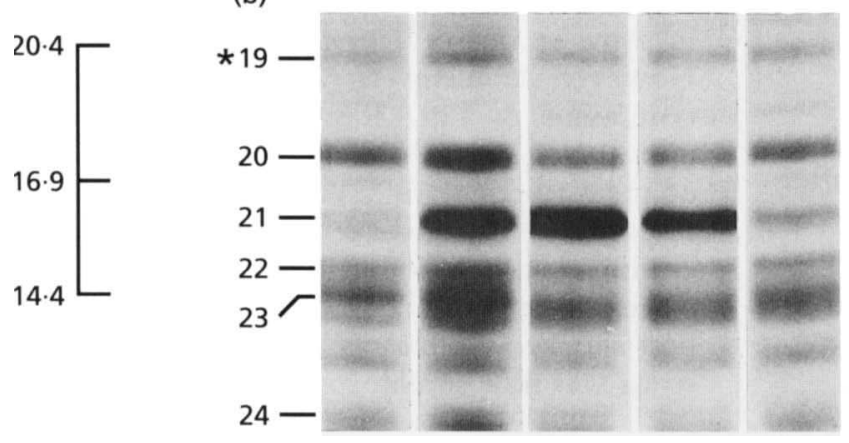

Fig. 2. Fluorograms of SDS-polyacrylamide gels of ${ }^{35}$ S-labelled proteins synthesized during heat shock in exponentially growing V. cholerae MAK757: (a) $10 \%$ and (b) $12.5 \%$ polyacrylamide gels. A mid-exponentialphase culture growing at $30^{\circ} \mathrm{C}$ was divided into two parts. One part was kept at $30^{\circ} \mathrm{C}$; the other part was heat-shocked to $42^{\circ} \mathrm{C}$ (time 0 ). Cells were then labelled for $7 \mathrm{~min}$ with $\left[{ }^{35} \mathrm{~S}\right.$ ]methionine at the times indicated: lane $1,0-7 \mathrm{~min}$ at $30^{\circ} \mathrm{C}$ (control); lane 2. $0-7 \mathrm{~min}$ at $42{ }^{\circ} \mathrm{C}$; lane $3,7-14 \mathrm{~min}$ at $42{ }^{\circ} \mathrm{C}$; lane 4, 14-21 $\mathrm{min}$ at $42{ }^{\circ} \mathrm{C}$; lane $5,21-28 \mathrm{~min}$ at $42{ }^{\circ} \mathrm{C}$. Numbers on the left indicate the Hsps induced. The asterisks identify the $20.3 \mathrm{kDa}$ Hsp, band 19, in the two gel systems. Arrows indicate Hsps synthesized de novo. The capital letters indicate the proteins whose synthesis decreased upon heat shock (see text for further details). Positions of the molecular mass markers are shown on the far left: (a) bovine serum albumin (66 kDa), egg albumin ( $45 \mathrm{kDa})$, glyceraldehyde-3-phosphate dehydrogenase (36 kDa), carbonic anhydrase $(29 \mathrm{kDa})$, trypsinogen (24 kDa) (Sigma); (b) soybean trypsin inhibitor (doublet, 20.4 and $19.7 \mathrm{kDa})$, horse heart myoglobin (16.9 kDa) and lysozyme (14.4 kDa) (Promega). detectable, as measured by incorporation of $\left[{ }^{35} \mathrm{~S}\right]$ methionine into TCA-precipitable material. Patterns of proteins synthesized after heat shock to $42^{\circ} \mathrm{C}$ analysed by one-dimensional SDS-PAGE followed by Coomassie staining revealed induction of five proteins, of $38,60,65$, 68 and $80 \mathrm{kDa}$ (data not shown). When a similar experiment was performed, in which cells were labelled with $\left[{ }^{35} \mathrm{~S}\right]$ methionine for $7 \mathrm{~min}$ at different times after the shiftup to $42^{\circ} \mathrm{C}$, a complex pattern of synthesis became discernible. Induction of 24 proteins, ranging from around 90 to $12 \mathrm{kDa}$ (Figs 2 and 3, bands 1-24; Table 2) could be seen. Of these, three proteins, of 48,44 and $38 \mathrm{kDa}$ (Figs 2a and 3a, lane 2, bands 10, 11 and 13 respectively), appeared de novo. Among these Hsps, two temporal classes could be distinguished. Enhanced synthesis of 22 proteins belonging to the first class, represented by bands $1,3,4,5$ and 7 to 24 , occurred immediately after the heat shock (Figs 2 and 3, lane 2), while the enhanced synthesis of the second class of proteins, viz. bands 2 and 6 , required between 14 to $28 \mathrm{~min}$ at the elevated temperature (Figs 2 and 3, lanes 5 and 4 , respectively).

The 22 proteins in the first temporal class could be subclassified into three groups based upon their patterns of synthesis. The first sub-group of proteins (bands 1, 7, 9, $11,12,14,15,17-20,22$ and 23) showed a rapid burst of synthesis, followed by a transient decline and subsequent recovery (Figs 2 and 3). The second sub-group comprised those proteins which continued to be synthesized at a steady rate for $21 \mathrm{~min}$ or more after the heat shock; proteins represented by bands 3, 4, 5, 8 and 21 (Figs 2 and 3 ), of which bands 3 and $5(68$ and $60 \mathrm{kDa}$ ) were subsequently identified as the DnaK and GroEL homologues, were in this class. The third sub-group comprised the proteins (bands 10,13, 16 and 24; Figs 2 and 3 ) whose synthesis showed a decline after the initial burst during the first $7 \mathrm{~min}$ at $42^{\circ} \mathrm{C}$ (Figs 2 and 3). 

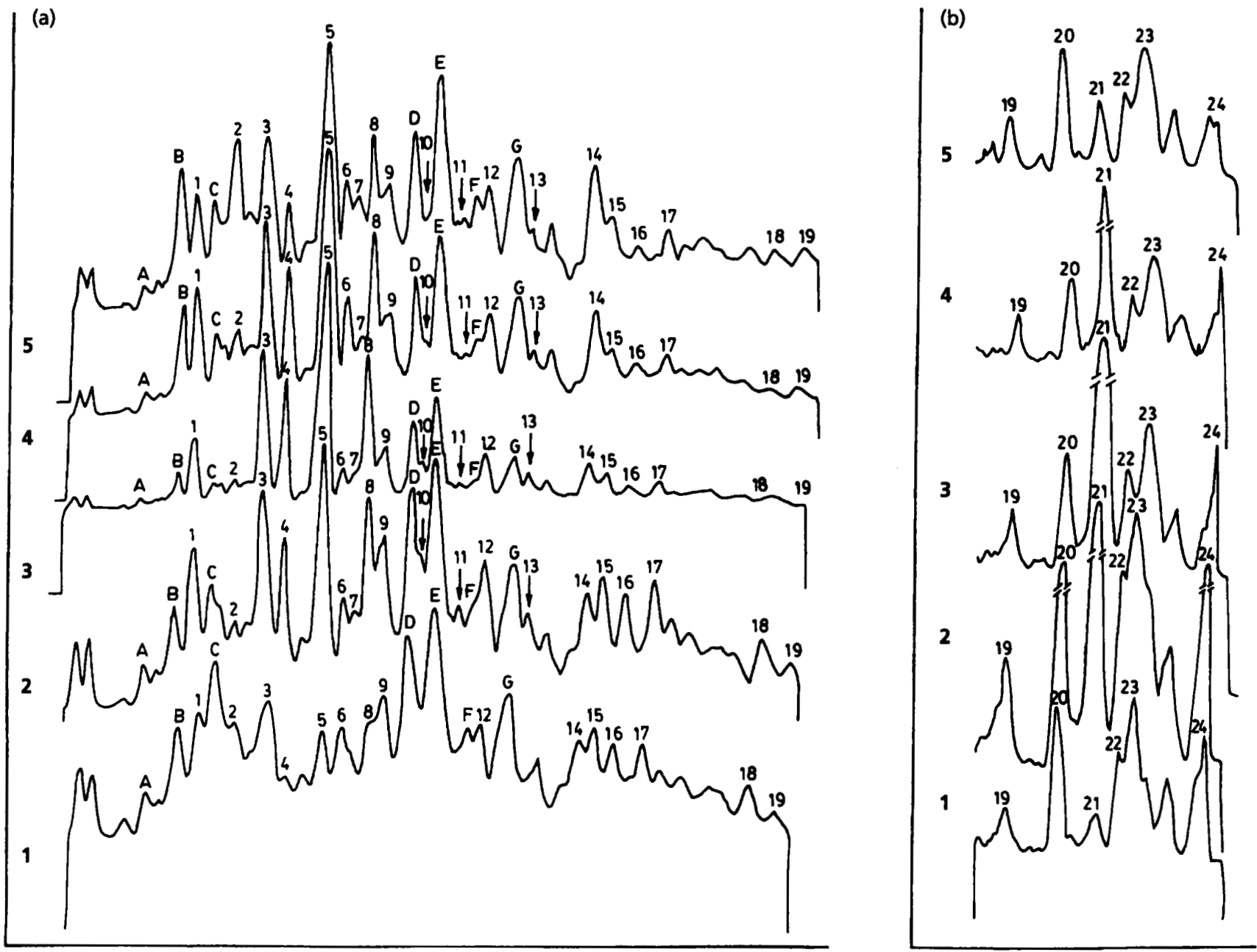

Fig. 3. Densitometric scans of the fluorograms shown in Fig. 2. Parts (a) and (b) correspond to those of Fig. 2. The numbers on the left indicate the lanes in Fig. 2.

Table 2. Molecular masses of the Hsps of $V$. cholerae MAK757

The band numbers correspond to those indicated in Figs 2 and 3.

\begin{tabular}{|cccc|}
\hline $\begin{array}{l}\text { Band } \\
\text { no. }\end{array}$ & $\begin{array}{c}\text { Mol. } \\
\text { mass } \\
\text { (kDa) }\end{array}$ & $\begin{array}{c}\text { Band } \\
\text { no. }\end{array}$ & $\begin{array}{c}\text { Mol. } \\
\text { mass } \\
\mathbf{( k D a )}\end{array}$ \\
\hline 1 & $88 \cdot 1$ & 13 & $38 \cdot 3$ \\
2 & $78 \cdot 6$ & 14 & $33 \cdot 4$ \\
3 & $68 \cdot 5$ & 15 & $32 \cdot 1$ \\
4 & $66 \cdot 0$ & 16 & $30 \cdot 8$ \\
5 & $60 \cdot 7$ & 17 & $28 \cdot 0$ \\
6 & $58 \cdot 2$ & 18 & $22 \cdot 0$ \\
7 & $56 \cdot 6$ & 19 & $20 \cdot 3$ \\
8 & $55 \cdot 4$ & 20 & $17 \cdot 5$ \\
9 & $52 \cdot 8$ & 21 & $16 \cdot 0$ \\
10 & $48 \cdot 05$ & 22 & $15 \cdot 0$ \\
11 & $44 \cdot 3$ & 23 & $14 \cdot 5$ \\
12 & $40 \cdot 9$ & 24 & $12 \cdot 1$ \\
\hline
\end{tabular}

Compared to the control, a reduction in the synthesis of a number of proteins (bands A, B, C, D, E, F and G, Figs $2 a$ and $3 a$ ) was also seen as the consequence of heat shock. Here again two temporal classes could be observed: synthesis of the protein represented by band $C$ declined immediately after the heat shock and did not attain the control level again (Figs $2 a$ and $3 a$ ) while the synthesis of five other proteins (bands A, B, D, E, F and G; Figs 2a and $3 a$ ) declined transiently after the heat shock and then resumed again.

\section{Identification of Hsps}

A comparison of the molecular masses of proteins of $V$. cholerae that showed enhanced synthesis upon heat shock with those of E. coli revealed that a number of Hsps from these two organisms had similar or identical molecular masses. Two $V$. cholerae proteins which showed maximal enhancement (bands 3 and 5 in Figs 2 and 3 ) had molecular masses around 68 and $60 \mathrm{kDa}$ respectively, similar to the 68 and $62.9 \mathrm{kDa}$ of the E. coli Hsps DnaK and GroEL. 
(a)

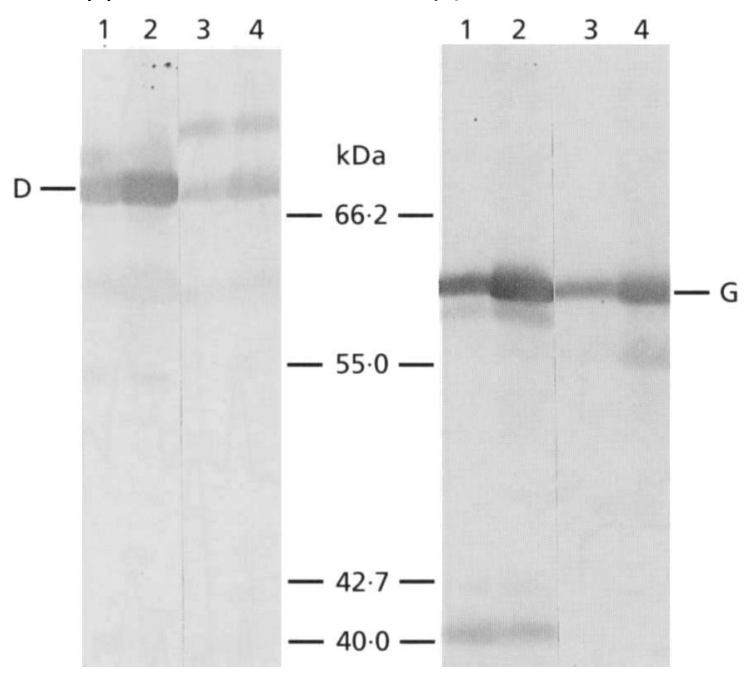

Fig. 4. Immunoblots showing the presence of homologues of $E$. coli DnaK and GroEL proteins in V. cholerae MAK757. Cell lysates from control (grown at $30^{\circ} \mathrm{C}$ ) and heat-shocked (to $42^{\circ} \mathrm{C}$ for $20 \mathrm{~min}$ ) cultures of $V$. cholerae MAK757 and E. coli B were analysed by SDS-PAGE $(8 \%)$ and immunoblotted with $E$. coli anti-DnaK (a) and anti-GroEL (b) antibodies. Lanes (a and b) : $1, E$. coli control; $2, E$. coli heat-shocked; $3, V$. cholerae control; $4, V$. cholerae heat-shocked. The positions of DnaK and GroEL are indicated by D and G, respectively. Positions of the molecular mass markers (Promega), bovine serum albumin $(66.2 \mathrm{kDa})$, glutamate dehydrogenase $(55 \mathrm{kDa})$, ovalbumin $(42.7 \mathrm{kDa})$ and aldolase $(40 \mathrm{kDa})$ are indicated.

These two proteins play essential roles in the normal physiology of E. coli and are widely conserved in nature (Parsell \& Lindquist, 1993).
To determine whether the $V$. cholerae proteins were indeed the homologues of DnaK and GroEL of E. coli, Western blot analysis was carried out with antibodies prepared against the E. coli DnaK and GroEL proteins (Fig. 4). The $68 \mathrm{kDa} \mathrm{Hsp}$ of $V$. cholerae showed strong cross-reactivity with the E. coli DnaK antibodies (Fig. 4a) while the $60 \mathrm{kDa}$ protein reacted strongly with $E$. coli GroEL antibodies (Fig. 4b). Further, the presence of bands of reasonable intensity corresponding to these proteins in the control lane (Fig. $4 \mathrm{a}, \mathrm{b}$, lane 3) indicated that these proteins are synthesized constitutively in $V$. cholerae. The protein in E. coli which cross-reacted with $E$. coli anti-GroEL antibodies showed an apparent molecular mass of $60 \mathrm{kDa}$, the same as that shown by the $V$. cholerae GroEL homologue (Fig. 2, band 5, Fig. 4b). This value differs from the reported value of $62883 \mathrm{Da}$ for the E. coli GroEL based on the sequence data (Neidhardt \& Van Bogelen, 1987). This difference perhaps reflects the discrepancy between the true molecular mass based on the sequence data and the apparent one as determined by SDS-PAGE. Depending upon the SDS-PAGE conditions used in different studies, a range of values (56 to $70 \mathrm{kDa}$ ) has been reported for GroEL (Visentin et al., 1977; Georgopoulos \& Hohn, 1978; Hendrix \& Tsui, 1978; Pedersen et al., 1978; Hendrix, 1979; Hohn et al., 1979; Neidhardt et al., 1981). It is therefore possible that the true molecular mass of $V$. cholerae GroEL is actually closer to $63 \mathrm{kDa}$ rather than to $60 \mathrm{kDa}$ as we found from our SDS-PAGE analysis. It was of particular interest that a clear-cut induction of these Hsps also occurred when $V$. cholerae growing at $30^{\circ} \mathrm{C}$ was heat-shocked to $37^{\circ} \mathrm{C}$ - the body temperature in humans (data not shown). Despite the fact that the temperature upshift was only of $7^{\circ} \mathrm{C}$, the induction of both DnaK and GroEL proteins in the Western blot was considerable. (a)

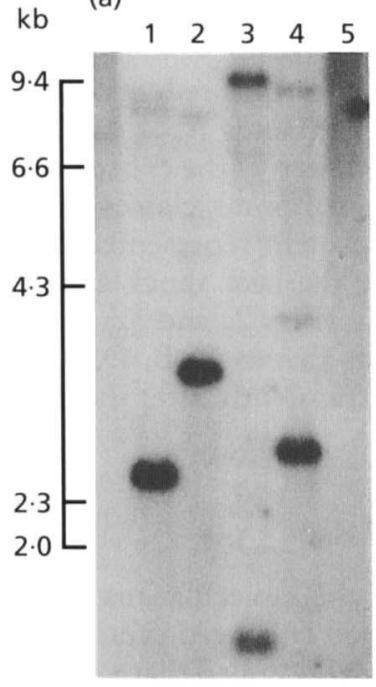

(b)

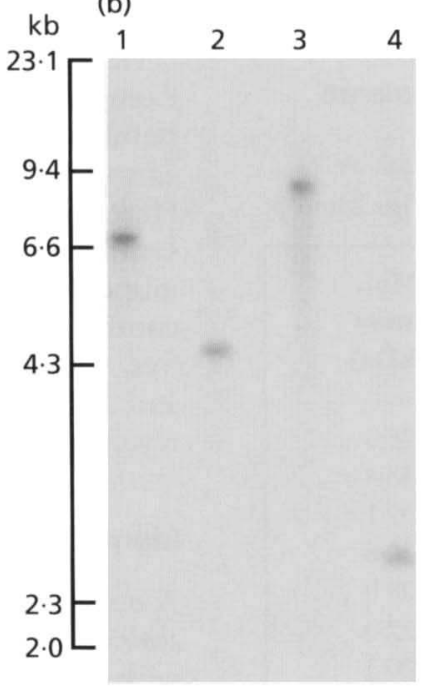

(c)

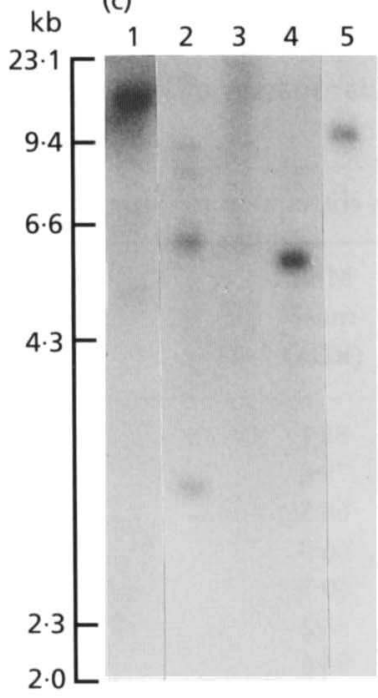

Fig. 5. Southern blot analysis of restricted $V$. cholerae MAK757 DNA with E. coli dnaK (a), dnaJ (b) and groEL (c) probes. Restriction enzymes used in (a) and (b): lane 1, Clal; lane 2, Hindill; lane 3, EcoRI; lane 4, Pstl; lane 5 (a only), Pvul. For (c) the enzymes used were: lane 1, Bg/lI; lane 2, EcoRV; lane 3, Hpal; lane 4, HindIII; lane 5, Sall. Positions of $\lambda$-HindIII molecular size markers run on the same gel are indicated. 


\section{Evidence for the presence of dnaJ-, dnaK- and groE- like sequences in $V$. cholerae}

The DnaK protein or its homologues act as molecular chaperones, taking part in the proper folding of protein molecules in E. coli. In E. coli DnaK does not function alone but acts along with the other chaperone proteins DnaJ and GrpE, with the GroEL protein providing a scaffolding where the entire folding process can take place (Martin \& Hartl, 1993). The presence of both DnaK and GroEL in $V$. cholerae and the presence of other proteins with molecular masses similar to E. coli DnaJ and GrpE prompted us to examine whether homologues of these also exist in $V$. cholerae. In the absence of antisera against these proteins, we decided to look for the corresponding genes by Southern hybridization with appropriate gene probes. Genomic DNA from $V$. cholerae was isolated, digested with several restriction endonucleases, Southern hybridized and then probed for $d n a K, d n a J, g r o E$ and $\operatorname{gr} p E$ as described in Methods. Signals of considerable strength were obtained for $d n a K, d n a J$ and groE (Fig. 5). No signal, however, could be obtained for $g r p E$.

\section{DISCUSSION}

The data presented in this paper demonstrate that $V$. cholerae exhibits a heat shock response which is quite similar to that displayed by the well-characterized E. coli system. The observation that a $7^{\circ} \mathrm{C}$ temperature upshift from $30^{\circ} \mathrm{C}$ to $37^{\circ} \mathrm{C}$ could trigger the heat shock response in $V$. cholerae is significant since $37^{\circ} \mathrm{C}$ is the physiological temperature in its human hosts. This phenomenon has been put to ingenious use recently (Taylor $e t$ al., 1994) in the construction of live attenuated oral vaccine strains of $V$. cholerae. Epidemic strains were first attenuated by deleting the so-called virulence cassette and the RS1 element from these strains. The gene for the immunogenic ' $B$ ' subunit of the cholera toxin was then reintroduced into these under the control of the btpG heat shock promoter, thereby ensuring optimal expression of the ${ }_{\operatorname{ct}} \mathrm{B}$ gene in these vaccine strains in the human host.

A total of 24 Hsps could be detected by one-dimensional SDS-PAGE of cells shocked from $30^{\circ} \mathrm{C}$ to $42^{\circ} \mathrm{C}$. Many of these proteins had molecular masses similar to those reported for $E$. coli $\mathrm{Hsps}$, and immunoblotting established the presence in $V$. cholerae of homologues of DnaK and GroEL of E. coli. However, unlike in E. coli, where DnaK is induced to a higher level than GroEL (Neidhardt \& Van Bogelen, 1987), in $V$. cholerae GroEL was induced to a higher level than DnaK (Fig. 3). An interesting observation was that unlike in E. coli, where these genes are activated to a maximal level about 5 min after a shiftup in temperature and then decline to a new level only slightly higher than that before the temperature shift-up, in $V$. cholerae these genes continued to be expressed at a much higher level after the heat shock, compared to the control, during the entire period ( $28 \mathrm{~min}$ ) of study (Fig. 2, bands 3 and 5).

Southern blot analysis of $V$. cholerae genomic DNA with heterologous E. coli dnaK, groEL and dnaJ probes revealed the presence of sequences homologous to these in $V$. cholerae, making it tempting to speculate that a protein analogue of DnaJ also exists in $V$. cholerae. However, hybridization experiments failed to detect the presence of a sequence homologous to grp $E$ of $E$. coli in $V$. cholerae. This result was rather surprising because DnaK, Dna J, GroEL and GrpE proteins are all known to be widely conserved in nature, and our experiments revealed that not only DnaK and GroEL of $V$. cholerae are homologous to their counterparts in E. coli but also that equivalents of $d n a K$, groEL and dnaJ of $E$. coli exist in $V$. cholerae.

Like $E$. coli $\mathrm{B}, V$. cholerae became more thermotolerant and UV sensitive as a result of heat shock. The ability of E. coli B to develop thermal resistance and UV sensitivity after a heat shock treatment has been traced to the absence of the lon gene in this organism (Pardasani et al., 1989). No information on the status of this gene in $V$. cholerae MAK 757 is available, but it is tempting to speculate, on the basis of our results, that MAK757 could be a naturally occurring lon strain. It ought to be mentioned, however, that even though the induction of thermotolerance in $V$. cbolerae coincided with the induction of Hsps, in the light of recent evidence in E. coli (Ramsay, 1988) and yeast (Cavicchioli \& Watson, 1986) it cannot be concluded unequivocally that the observed thermotolerance in $V$. cholerae was a direct consequence of the heat shock response.

One aspect of the heat shock response in which $V$. cholerae differed significantly from $E$. coli was in the effect of heat shock on phage yield. While a great enhancement in progeny virus production is observed in heat-shocked $E$. coli (Wiberg et al., 1988) the effect was only marginal in $V$. cholerae.

After this paper was submitted a report directed at identifying the major heat shock antigens of $V$. cholerae was published (Sahu et al., 1994). Although the results obtained are in broad agreement there are a few points of disagreement. Sahu et al. (1994) found that $16 \mathrm{Hsps}$ are induced in $V$. cholerae $569 \mathrm{~B}$ as the result of temperature shift-up. In contrast we found that a total of 24 proteins are induced/synthesized de novo in $V$. cholerae MAK757 after the cells are shifted from $30^{\circ} \mathrm{C}$ to $42{ }^{\circ} \mathrm{C}$. These include those reported by Sahu et al. (1994), plus another eight which were not detected by them. We were able to identify these, using a combination of 10.0 and $12.5 \%$ SDS-PAGE. Since these patterns were obtained reproducibly, the discrepancy could perhaps be attributed to the different strains used. We observe that the $16 \mathrm{kDa}$ Hsp is one of the three major Hsps induced upon heat shock, the other two being DnaK and GroEL. This observation concurs with that of Sahu et al. (1994), though it differs from their observation that this $16 \mathrm{kDa}$ Hsp could be detected at a very low level on overloaded gels if a laboratory-maintained culture of $V$. cholerae $569 \mathrm{~B}$ was used. We could obtain a very strong induction of this Hsp in the laboratory-maintained culture of MAK757 (Fig. 2, band 21). Once again we do not know the reason for this difference. It could possibly be because of some difference in the classical 569B and El Tor MAK757 
strains of $V$. cholerae. The third point where our results differ is in the kinetics of induction of some Hsps. Sahu et al. (1994) reported that all Hsps are induced within $10 \mathrm{~min}$ of temperature shift-up, whereas we could detect the induction of two proteins (bands 2 and 6 , of 78.6 and $58.2 \mathrm{kDa}$; Figs 2 and 3) only after 21 and $14 \mathrm{~min}$ of heat shock respectively. These differences apart, most of the results presented in the two papers are complementary and there is broad agreement wherever there is an overlap.

In conclusion, it may be stated that even though E. coli and $V$. cholerae diverged some 670 million years ago (Yamamoto et al., 1987), $V$. cholerae responds to heat shock in a manner very similar to E. coli, and almost all the proteins which make up the chaperone machinery in $E$. coli are also present in this organism.

\section{ACKNOWLEDGEMENTS}

We thank Dr Kit Tilly, Rocky Mountain Laboratories, USA, for kindly providing the plasmids, and Dr Roger McMacken, Johns Hopkins University, Dr Kathee Martincic, University of Pittsburgh and Dr Dhruba Chattoraj, NIH, USA, for antibodies against E. coli DnaK and GroEL. Financial assistance provided by CSIR and Department of Biotechnology (Grant no. BT/TF/9/63/91), Government of India, is duly acknowledged.

\section{REFERENCES}

Bardwell, J. C. A. \& Craig, E. A. (1984). Major heat shock gene of Drosopbila and the Escherichia coli heat inducible dnaK gene are homologous. Proc Natl Acad Sci US A 81, 848-852.

Bardwell, J. C. A., Tilly, K., Craig, E., King, J., Zylicz, M. \& Georgopulos, C. (1986). The nucleotide sequence of the Escherichia coli ${\mathrm{K} 12 ~ d n a J^{+}}$gene - a gene that encodes a heat shock protein. J Biol Chem 261, 1782-1785.

Basu, R. \& Ghosh, A. (1987). Inducible reactivation of UVirradiated cholera phage 5 in Vibrio cholerae MAK757. Mol \& Gen Genet 209, 175-178.

Basu, R., Ghosh, A. N., Dasgupta, S. \& Ghosh, A. (1993). Biophysical characterization of Vibrio $\mathrm{El}$ Tor typing phage e5. FEMS Microbiol Lett 106, 9-18.

Bhasin, N. \& Ghosh, A. (1995). Evidence for a weak adaptive response to alkylation damage in Vibrio cbolerae. Mutat Res 336, 79-89.

Bradford, M. M. (1976). A rapid and sensitive method for the quantitation of microgram quantities of protein utilizing the principle of protein-dye binding. Anal Biochem 72, 248-254.

Cavicchioli, R. \& Watson, K. (1986). Loss of heat-shock acquisition of thermotolerance in yeast is not correlated with loss of heat-shock proteins. FEBS Lett 207, 149-152.

Chakravarti, D. \& Ghosh, A. (1987). Reversal by cyclic AMP of the urea-induced inhibition of synthesis of a catabolite-repressible enzyme in Vibrio cholerae. J Gen Microbiol 133, 3265-3270.

Chandrasekhar, G. N., Tilly, K., Woolford, C., Hendrix, R. \& Georgopoulos, C. (1986). Purification and properties of the groES morphogenetic protein of Escherichia coli. J Biol Chem 261, 12414-12419.

Churchward, G., Belin, D. \& Nagamine, Y. (1984). A pSC101 derived plasmid which shows no sequence homology to other commonly used cloning vectors. Gene 31, 165-171.

Dascher, C. C., Poddar, S. K. \& Maniloff, J. (1990). Heat shock response in mycoplasmas, genome-limited organisms. J Bacteriol 172, 1823-1827.

Ellis, E. L. \& Delbruck, M. (1939). The growth of bacteriophage. $J$ Gen Pbysiol 22, 365-384.

Epstein, P. R., Ford, T. E. \& Colwell, R. R. (1993). Marine ecosystems. Lancet 342, 1216-1219.

Georgopoulos, C. P. \& Hohn, B. (1978). Identification of a host protein necessary to bacteriophage morphogenesis (the groE gene product). Proc Natl Acad Sci US A 75, 131-135.

Ghosh, A., Maniloff, J. \& Gerling, D. A. (1978). Inhibition of Mycoplasma cell division by cytochalasin B. Cell 13, 57-64.

Hatchard, C. G. \& Parker, C. A. (1956). A new sensitive chemical actinometer. II. Potassium ferrioxalate as a standard chemical actinometer. Proc R Soc Lond Ser A 235, 518-536.

Hendrix, R. W. (1979). Purification and properties of groE, a host protein involved in bacteriophage assembly. $J$ Mol Biol 129, 375-392.

Hendrix, R. W. \& Tsui, L. (1978). Role of the host in virus assembly: cloning of the $E$. coli groE gene and identification of its protein product. Proc Natl Acad Sci US A 75, 136-139.

Hohn, T., Hohn, B., Engel, A., Wurtz, M. \& Smith, P. R. (1979). Isolation and characterization of the host protein groE involved in bacteriophage lambda assembly. J Mol Biol 129, 359-373.

Laemmli, U. K. (1970). Cleavage of structural proteins during the assembly of the head of bacteriophage T4. Nature 227, 680-685.

Maloy, S. R. (1990). Characterization of auxotrophic requirements. In Experimental Techniques in Bacterial Genetics, pp. 25-26. London: Jones \& Bartlet.

Martin, J. \& Hartl, F. U. (1993). Protein folding in the cell: molecular chaperones pave the way. Structure 1, 161-164.

McAlister, L. \& Finkelstein, D. B. (1980). Heat shock proteins and thermal resistance in yeast. Biochem Biopbys Res Commun 93, 819-824.

Mekalanos, J. J. (1983). Duplication and amplification of toxin genes in Vibrio cholerae. Cell 35, 253-263.

Mitra, S., Ghosh, A. \& Ghosh, R. K. (1986). Metabolic reactions responsible for glucose stimulation of alkaline phosphatase in Vibrio cholerae. J Gen Microbiol 132, 2601-2603.

Neidhardt, F. C. \& Van Bogelen, R. A. (1987). Heat shock response. In Escherichia coli and Salmonella typhimurium: Cellular and Molecular Biology, vol. 2, pp. 1334-1345. Edited by F. C. Neidhardt, J. L. Ingraham, K. Brooks Low, B. Magasanik, M. Schaechter \& H. E. Umbarger. Washington, DC: American Society for Microbiology.

Neidhardt, F. C., Phillips, T. A., Van Bogelen, R. A., Smith, M. W., Georgalis, Y. \& Subramanian, A. R. (1981). Identity of the B56.5 protein, the A protein, and the groE gene product of Escherichia coli. $J$ Bacteriol 145, 513-520.

Pardasani, D. \& Fitt, P. S. (1989). Strain dependent induction by heat shock of resistance to ultraviolet light in Escherichia coli. Curr Microbiol 18, 99-103.

Pardasani, D., Sharma, N. \& Fitt, P. S. (1989). Dependence on the lon gene of the thermal induction of resistance to ultraviolet light in Escherichia coli. Curr Microbiol 19, 129-133.

Parsell, D. A. \& Lindquist, S. (1993). The function of heat-shock proteins in stress tolerance: degradation and reactivation of damaged proteins. Annu Rev Genet 27, 436-496.

Parsot, C. \& Mekalanos, J. J. (1990). Expression of Tox R, the transcriptional activator of the virulence factors in Vibrio cholerae, is modulated by the heat shock response. Proc Natl Acad Sci US A 87, 9898-9902.

Pedersen, S., Bloch, P. L., Reeh, S. \& Neidhardt, F. C. (1978). 
Patterns of the amount of 140 individual proteins at different growth rates. Cell 14, 179-190.

Plesofsky-Vig, N. \& Brambl, R. (1985). Heat shock response of Neurospora crassa: protein synthesis and induced thermotolerance. $J$ Bacteriol 162, 1083-1091.

Ramsay, N. (1988). A mutant in a major heat shock protein of Escherichia coli continues to show inducible thermotolerance. Mol \& Gen Genet 211, 332-334.

Rigby, P. W., Dieckmann, M., Rhodes, C. \& Berg, P. (1977). Labelling deoxyribonucleic acid to high specific activity in vitro by nick translation with DNA polymerase I. J Mol Biol 113, 237-251.

Sahu, G. K., Chowdhury, R. \& Das, J. (1994). Heat shock response and heat shock protein antigens of $V$ ibrio cholerae. Infect Immun 62, 5624-5631.

Sambrook, J., Fritsch, E. F. \& Maniatis, T. (1989). Molecular Cloning: a Laboratory Manual, 2nd edn. Cold Spring Harbor, NY: Cold Spring Harbor Laboratory.

Siddiqui, K. A. I. \& Ghosh, A. (1983). Temperate phage induction and filament formation in Vibrio cholerae by furazolidone. Biocbem Biopbys Res Commun 112, 1106-1111.

Taylor, D. N., Killeen, K. P., Hack, D. C., Kenner, J. R., Coster, T. S., Beattie, D. T., Ezzell, J., Hyman, T., Trofa, A., Sjogren, M. H.,
Friedlander, A., Mekalanos, J. J. \& Sadoff, J. C. (1994). Development of a live, oral, attenuated vaccine against $\mathrm{El}$ Tor cholera. J Infect Dis 170, 1518-1523.

Vaughan, P., Sedgwick, B., Hall, J., Gannon, J. \& Lindahl, T. (1991). Environmental mutagens that induce the adaptive response to alkylating agents in Eschericbia coli. Carcinogenesis 12, 263-268.

Visentin, L. P., Hasnain, S., Gallin, W., Johnson, K. G., Griffith, D. W. \& Wahba, A. J. (1977). Ribosomal protein $\mathrm{S} 1 / \mathrm{S} 1 \mathrm{~A}$ in bacteria. FEBS Lett 79, 255-263.

Watson, K. (1990). Microbial stress proteins. Adv Microb Pbysiol 31, 183-216.

Wiberg, J. S., Mowree-McKee, M. F. \& Stevens, E. J. (1988). Induction of the heat shock regulon of Escherichia coli markedly increases production of bacterial viruses at high temperature. $J$ Virol 62, 234-245.

Yamamoto, T., Gojobori, T. \& Yokota, T. (1987). Evolutionary origin of pathogenic determinants in enterotoxigenic Escherichia coli and Vibrio cholerae O1. J Bacteriol 169, 1352-1357.

Yura, T., Nagai, H. \& Mori, H. (1993). Regulation of the heat shock response in bacteria. Annu Rev Microbiol 47, 321-350.

Received 31 October 1994; revised 2 May 1995; accepted 12 May 1995. 